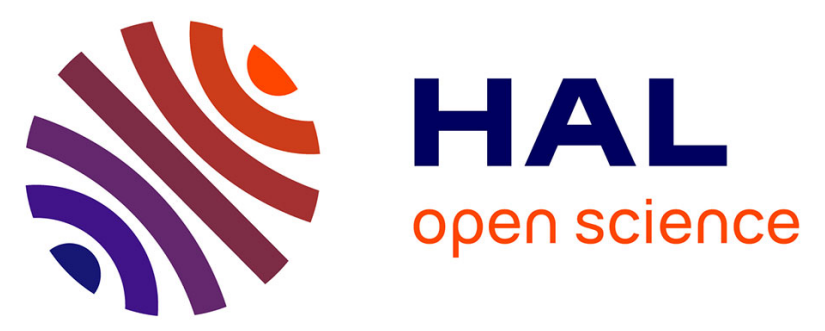

\title{
Cell proliferation and cell death are disturbed during prenatal and postnatal brain development after uranium exposure
}

Marie Legrand, Christelle Elie, Johanna Stefani, Nicole Florès, Cécile Culeux, Olivia Delissen, Chrystelle Ibanez, Philippe Lestaevel, Per Olof Eriksson, Céline Dinocourt

\section{To cite this version:}

Marie Legrand, Christelle Elie, Johanna Stefani, Nicole Florès, Cécile Culeux, et al.. Cell proliferation and cell death are disturbed during prenatal and postnatal brain development after uranium exposure. NeuroToxicology, 2016, 52, pp.34-45. 10.1016/j.neuro.2015.10.007 . hal-02557556

\author{
HAL Id: hal-02557556 \\ https://hal.science/hal-02557556
}

Submitted on 22 Oct 2021

HAL is a multi-disciplinary open access archive for the deposit and dissemination of scientific research documents, whether they are published or not. The documents may come from teaching and research institutions in France or abroad, or from public or private research centers.
L'archive ouverte pluridisciplinaire HAL, est destinée au dépôt et à la diffusion de documents scientifiques de niveau recherche, publiés ou non, émanant des établissements d'enseignement et de recherche français ou étrangers, des laboratoires publics ou privés. 


\title{
Cell proliferation and cell death are disturbed during prenatal and postnatal brain development after uranium exposure
}

\author{
M. Legrand ${ }^{\text {a }}$, C. Elie $^{\text {a }}$, J. Stefani ${ }^{\text {a }}$, N.Florès ${ }^{\text {a }}$, C. Culeux ${ }^{a}$, O. Delissen ${ }^{\text {a }}$, C. Ibanez $^{\text {a }}$, \\ P. Lestaevel ${ }^{\text {a }}$, P. Eriksson ${ }^{\mathrm{b}}$, C. Dinocourt ${ }^{\mathrm{a}, *}$ \\ ${ }^{a}$ Laboratoire de RadioToxicologie Expérimentale, Service de Radiobiologie et d'Epidémiologie, Institut de Radioprotection et Sûreté Nucléaire, B.P. 17, \\ 92262 Fontenay aux Roses Cedex, France \\ ${ }^{\mathrm{b}}$ Department of Environmental Toxicology, Uppsala University, Norbyvägen 18 A, 75236 Uppsala, Sweden
}

The developing brain is more susceptible to neurotoxic compounds than adult brain. It is also well known that disturbances during brain development cause neurological disorders in adulthood. The brain is known to be a target organ of uranium (U) exposure and previous studies have noted that internal $\mathrm{U}$ contamination of adult rats induces behavioral disorders as well as affects neurochemistry and neurophysiological properties. In this study, we investigated whether depleted uranium (DU) exposure affects neurogenesis during prenatal and postnatal brain development. We examined the structural morphology of the brain, cell death and finally cell proliferation in animals exposed to DU during gestation and lactation compared to control animals. Our results showed that DU decreases cell death in the cortical neuroepithelium of gestational day (GD) 13 embryos exposed at $40 \mathrm{mg} / \mathrm{L}$ and 120 $\mathrm{mg} / \mathrm{L}$ and of GD18 fetuses exposed at $120 \mathrm{mg} / \mathrm{L}$ without modification of the number of apoptotic cells. Cell proliferation analysis showed an increase of BrdU labeling in the dentate neuroepithelium of fetuses from GD18 at $120 \mathrm{mg} / \mathrm{L}$. Postnatally, cell death is increased in the dentate gyrus of postnatal day (PND) 0 and PND5 exposed pups at $120 \mathrm{mg} / \mathrm{L}$ and is associated with an increase of apoptotic cell number only at PND5. Finally, a decrease in dividing cells is observed in the dentate gyrus of PND21 rats developmentally exposed to $120 \mathrm{mg} / \mathrm{L} \mathrm{DU}$, but not at PND0 and PND5. These results show that DU exposure during brain development causes opposite effects on cell proliferation and cell death processes between prenatal and postnatal development mainly at the highest dose. Although these modifications do not have a major impact in brain morphology, they could affect the next steps of neurogenesis and thus might disrupt the fine organization of the neuronal network.

\section{Introduction}

During development, the brain is sensitive to injury from neurotoxic agents (Rice and Barone, 2000). Developmental exposure to heavy metals can interfere with the processes of neurogenesis that lead to neuron generation during central nervous system formation: cell proliferation, migration, differentiation, synaptogenesis and cell death (Gotz and Huttner, 2005).

\footnotetext{
* Corresponding author. Present address: IRSN, Direction de la Stratégie du Développement et des Partenariats, Service Programmes et Stratégies scientifiques. Tel.: +331583591 83; fax: +33158358467.

E-mail addresses: marie.legrand@irsn.fr (M. Legrand), christelle.elie@irsn.fr (C. Elie), johanna.stefani@irsn.fr (J. Stefani), nicole.flores@irsn.fr (N.Florès), cecile.culeux@gmail.com (C. Culeux), olivia.delissen@irsn.fr (O. Delissen), chrystelle.ibanez@irsn.fr (C. Ibanez), philippe.lestaevel@irsn.fr (P. Lestaevel), per.eriksson@ebc.uu.se (P. Eriksson), celine.dinocourt@irsn.fr (C. Dinocourt).
}

Uranium (U) is a heavy metal naturally found in the environment. Civilian and military uses of $U$ increase its concentration in the environment (Briner, 2010), and thus civilian populations can be chronically exposed to $U$ by ingestion of contaminated food and water (ATSDR, 2013). Depleted uranium (DU) is a by-product of uranium enrichment for nuclear energy or weapons. It is an emerging environmental pollutant and has the same chemical toxicity as natural uranium, but is $40 \%$ less radioactive. Although DU accumulates more in the kidneys and bones, the brain is also a target organ (Lestaevel et al., 2005b). After chronic ingestion, $U$ found in the brain of adult rats was heterogeneously distributed in the cortex, striatum and hippocampus (Paquet et al., 2006). U may be able to cross the bloodbrain barrier by vascular transfer (Lemercier et al., 2003), but the precise mechanism of this transfer is not clearly demonstrated.

Epidemiologic studies show that cognitive impairment increases in populations exposed to U (Howland, 1948; McDiarmid 
et al., 2002). Experimental studies on adult rats have demonstrated that DU exposure by ingestion impairs cognitive functions. Subchronic and chronic exposure to DU induced an increase of paradoxical sleep (Lestaevel et al., 2005a), a reduction in spatial memory capacities, an increase in anxiety and a decrease of locomotor activity (Briner and Davis, 2002; Briner and Murray, 2005; Houpert et al., 2005).

Several mechanisms by which DU would be able to cause neurotoxicity and alter behavior have been explored. Alterations of the cholinergic system as well as of dopaminergic and serotoninergic metabolism (Bensoussan et al., 2009; Bussy et al., 2006) and disturbance of pro-/anti oxidant balance have been described after chronic ingestion of DU (Briner and Murray, 2005; Lestaevel et al., 2009).

Little is known about the toxicity of $U$ on the brain during its development. Most data on the perinatal and postnatal effects of DU in rodents have focused on developmental toxicity and fetal development effects (Domingo, 2001; Paternain et al., 1989). Briner and Abboud (2002) showed that mice exposed to DU during gestation and lactation exposed mothers via drinking water had a decrease of locomotor activity at the age of 3 weeks than controls. Parental exposure to enriched uranium as well as during gestation and lactation showed changes in postnatal development and decreased spatial working memory of the offspring (Houpert et al., 2007). In contrast, Sanchez et al. (2006) did not observe any disorders in spatial learning after exposure to natural uranium. Recent studies showed that DU exposure from birth to 10 weeks causes impairment of object recognition memory associated with a decrease of acetylcholine concentration and acetylcholinesterase activity (Lestaevel et al., 2013). In these exposed animals, a decrease of locomotor activity and a disturbance of anxiety with an increase of oxidative stress were also described (Lestaevel et al., 2015). Thus, possible effects of $U$ on neurobehavior and mechanisms underlying these effects during the sensitive early life stages of rats are insufficiently explored.

By its chemical properties, DU toxicity can be likened to heavy metal toxicity, of lead or cadmium, for example. It is well known that chronic exposure to heavy metal present in the environment during pregnancy and in infancy is associated with a risk of impaired cognitive development and behavioral alterations (Liu and Lewis, 2014). The mechanisms by which heavy metals alter behavior remain to be determined, but neurogenesis may be involved (Chow et al., 2008; Dou and Zhang, 2011; Liu and Lewis, 2014).

Likewise, DU might impair cognitive functions by acting on neurogenesis. Therefore, the aim of our study was to determine if DU exposure disturbs neurogenesis during brain development in rats. Morphogenesis, cell proliferation and cell death were studied at the prenatal, neonatal and postnatal stages. We focused on the telencephalon during embryonic and fetal brain development since it will give rise to the future cortex and hippocampus, which are involved in cognitive functions. In pups and young rats, we focused on the dentate gyrus (DG), which develops principally after birth and is one of the main neurogenic areas at the adult stage involved in synaptic plasticity and thus in cognitive functions (Ming and Song, 2005).

\section{Material and methods}

\subsection{Animals and contamination protocol}

Pregnant female Sprague-Dawley rats were received from Charles River (L'Arbresle, France) and used for the experiments. Pregnant females were housed alone under standard conditions with food and water provided ad libitum (light on: 8.00am/ $8.00 \mathrm{pm}$, temperature: $22{ }^{\circ} \mathrm{C} \pm 1{ }^{\circ} \mathrm{C}$ ). Body weight, food and water consumption were measured weekly. Pregnant females were exposed to DU (Areva-Cogema, France) via drinking water from the first day after mating (gestational day 1: GD1). The specific activity of DU is $14.103 \mathrm{~Bq} / \mathrm{g}$ and its isotopic composition is 238U: 99.73\%, 235U: $0.255 \%, 234 \mathrm{U}$ : $0.01 \%$. Pregnant rats were divided into three groups: control group, $40 \mathrm{mg} / \mathrm{L}$ DU group and $120 \mathrm{mg} / \mathrm{L}$ DU group. These concentrations were chosen from previous studies (Houpert et al., 2005; Briner and Murray, 2005). Based on water consumption of $100 \mathrm{~mL}$ daily, rats were exposed to 2 or $6 \mathrm{mg} / \mathrm{kg} / \mathrm{day}$, respectively. These doses are approximately equal to $1 / 100$ and $1 / 33$ of acute oral LD50 of $U$ in adult rats (Domingo et al., 1987). DU was dissolved in standardized mineral water. The animals of the control group drank mineral water of the same composition. The number of females was calculated with respect to the number of offspring needed for all experiments.

Pregnant females were divided in five time points during development: gestational day (GD) 13 (21 females), GD18 (18 females), postnatal day (PND) 0 (15 females), PND5 (15 females) and PND21 (18 females). Embryos, fetuses, neonatal and postnatal rats were taken for analysis as follows: 42 embryos from 21 litters at GD13, 33 fetuses from 17 litters at GD18, 30 male and female pups from 15 litters at PND0, 30 male and female pups from 15 litters at PND5 and 33 male pups from 18 litters at PND21.

All animal procedures were approved by the Animal Care Committee of IRSN and were conducted in accordance with French legislation and European legal requirements (Decree 86/609/EEC) concerning the protection of animals used for experimental purposes. Scientists certified by the French Ministry of Agriculture performed all procedures in animals.

\subsection{Tissue collection and preparation}

Pregnant rats were deeply anesthetized with isoflurane 5\%/air $95 \%$ inhalation and sacrificed by exsanguination. Kidneys of pregnant females were removed in order to measure the concentration of $U$ at each time point (GD13: $n=12$; GD18: $n=18$, PND0 and PND5: $n=15$, PND21: $n=18$ ). U concentrations were also measured in whole bodies of embryos from GD13 $(n=12)$, fetuses from GD18 $(n=18)$, in the bottom of the stomach, where the kidneys are localized, of pups from PND0 $(n=24)$ and PND5 $(n=24)$ and in kidneys from PND21 rats $(n=24)$. All samples were weighed and stored at $-20{ }^{\circ} \mathrm{C}$ until assay by ICP-MS.

For histology and immunochemistry, embryos from GD13 and fetuses from GD18 were collected, fixed in 4\% paraformaldehyde (PFA) for $1 \mathrm{~h}$ at room temperature (RT) and overnight at $4{ }^{\circ} \mathrm{C}$. Brains of PND0 and PND5 pups were collected and fixed in the same way as embryos and fetuses. PND21 rats were anesthetized with an intraperitoneal injection of $60 \mathrm{mg} / \mathrm{kg}$ sodium pentobarbital and were perfused transcardially with $4 \%$ PFA. Brains were removed and post-fixed for $1 \mathrm{~h}$ in $4 \%$ PFA at RT and overnight at $4{ }^{\circ} \mathrm{C}$. All heads of embryos and fetuses and brains of rat pups were washed in PBS $1 \mathrm{X}$ solution and stored in a $30 \%$ sucrose solution at $4{ }^{\circ} \mathrm{C}$. They were then embedded in Tissue-Tek OCT compound, frozen in a liquid nitrogen/isopentane mixture and kept at $-80^{\circ} \mathrm{C}$ until use. Embryos and heads of fetuses were sagittally sectioned and brains of pups were coronally sectioned with a cryostat at a thickness of $10 \mu \mathrm{m}$ or $20 \mu \mathrm{m}$. Brain sections were collected on superfrost slides and stored at $-80^{\circ} \mathrm{C}$ until use.

\subsection{Uranium concentration}

Samples were prepared by adding $8 \mathrm{~mL}$ of ultrapure $67-69 \%$ nitric acid and $2 \mathrm{~mL}$ of hydrogen peroxide and then mineralizing them in a $1000 \mathrm{~W}$ microwave (Ethos Touch; Milestone Microwave Laboratory Systems; Italy) with a 20 -min ramp to $180^{\circ} \mathrm{C}$ and then $10 \mathrm{~min}$ at $180^{\circ} \mathrm{C}$. U content from mineralized samples was 
determined with an inductively coupled plasma mass spectrometer (ICPMS-QX7-serie 2, Thermoelectron, France) with bismuth $(1 \mu \mathrm{g} / \mathrm{L})$ as the internal standard. The ICP-MS limit of detection for $\mathrm{U}$ is $104 \mu \mathrm{g} / \mathrm{L}$. Values were expressed as $\mathrm{ng} \mathrm{U} / \mathrm{g}$ tissue.

\subsection{Nissl staining}

Brain sections were hydrated in alcohol of descending concentration (95-80-70\%) and stained for $45 \mathrm{~s}$ in a cresyl violet solution. After a step of tissue differentiation in acetic formalin solution, sections were dehydrated in alcohol of ascending concentration (80-95-100\%), fixed in xylene and then coverslipped with Permount (Fishier Scientific, New Jersey).

Nissl staining was used to determine the general histological characteristics of the brain, especially in the telencephalic region for prenatal stages and in the hippocampus for neonatal and postnatal stages. Nissl staining allowed us to choose similar levels of the brain to compare the control and exposed animal groups. Two levels of embryonic and fetal brains (lateral and median) were selected and we focused on the telencephalon area (cortical, hippocampal and dentate neuroepithelia). At the different neonatal and postnatal stages, 4 levels of the brain were selected and the DG of the hippocampus was analyzed. From each prenatal, neonatal and postnatal brain, adjacent sections were processed for: (1) BrdU immunohistochemistry; (2) neuronal cell death method (fluorojade C) and (3) apoptosis detection (activated caspase-3). Brain sections from control and exposed animals were always processed in parallel.

\subsection{BrdU injection and immunohistochemistry}

In order to investigate the effect of DU on proliferation of progenitor cells, 5-bromo-2'deoxyuridine (BrdU, Sigma Aldrich, L'Isle D'Abeau Chesnes, France; $50 \mathrm{mg} / \mathrm{kg}$ prepared in sterile $\mathrm{NaCl}$ ) was injected intraperitoneally into pregnant females on GD13 and GD18 or into rat pups at PND0, PND5 and PND21. Cell proliferation was examined $4 \mathrm{~h}$ after BrdU injection at all time points, except for PND21 rats that received two injections of BrdU at 48 and $24 \mathrm{~h}$ before sacrifice. For immunochemistry, brain sections were rehydrated in phosphate-buffer saline $1 \mathrm{X}$ (PBS) and were incubated in $0.1 \%$ trypsin- $0.1 \% \mathrm{CaCl}_{2}$ diluted in distilled water for $20 \mathrm{~min}$ at $37^{\circ} \mathrm{C}$. Slices were treated to denature the DNA in $2 \mathrm{M}$ $\mathrm{HCL}$ for $30 \mathrm{~min}$ and were rinsed twice for $5 \mathrm{~min}$ in a borate buffer ( $55 \mathrm{~mL}$ of $0.2 \mathrm{M}$ boric acid/45 mL $0.05 \mathrm{M}$ sodium tetraborate, $\mathrm{pH}$ 8.4, Sigma Aldrich, L'Isle D'Abeau Chesnes, France). Sections were rinsed three times in PBS and incubated in a primary mouse monoclonal anti-BrdU antibody (1:50, Dako, Trappes, France) in PBS containing $0.3 \%$ Triton X-100 (PBS-T) for $30 \mathrm{~min}$ at RT and overnight at $4{ }^{\circ} \mathrm{C}$. Slices were washed three times in PBS and incubated with cyanine 3-conjugated donkey anti-mouse diluted in PBS-T (1:200, Jackson Immunoresearch, France) for $2 \mathrm{~h}$ at RT. Slides were then rinsed and mounted using Vectashield Dapicontaining medium (Vector Laboratories, Burlingame).

\subsection{Fluorojade staining}

Based on the protocol described by Schmued (Schmued et al., 2005), brain sections were dried overnight at $50{ }^{\circ} \mathrm{C}$ and immersed in a solution containing $1 \%$ sodium hydroxide in $80 \%$ alcohol for 5 min. Quickly rehydrated, they were incubated in $0.06 \%$ potassium permanganate for $5 \mathrm{~min}$. Slices were then rinsed in distilled water and transferred to $0.0004 \%$ fluorojade C (Millipore, France) solution for $10 \mathrm{~min}$. Finally, slices were washed in distilled water, dried at $50{ }^{\circ} \mathrm{C}$ for several minutes, immersed in xylene and coverslipped with Permount (Fisher Scientific).

\subsection{Cleaved caspase-3 immunohistochemistry}

Brain sections were rehydrated in PBS and incubated for $1 \mathrm{~h}$ in a blocking solution containing 5\% donkey serum in PBS-T at RT. Then they were incubated in an anti-cleaved caspase- 3 antibody $(1: 200$, Millipore, France) overnight at $4{ }^{\circ} \mathrm{C}$. Brain sections were washed in PBS $1 \mathrm{X}$ and incubated for $2 \mathrm{~h}$ at RT with alexa 488-conjugated donkey anti-rabbit diluted in PBS-T (1:200, Jackson Immunoresearch, France). Slices were finally washed and mounted using Vectashield Dapi-containing medium.

\subsection{Microscopy and quantitative analyses}

Nissl-stained slices were observed with a visible light optical microscope (Leica DM 4000B, Microvision, Evry, France) and slices stained for BrdU, fluorojade $\mathrm{C}$ or cleaved caspase-3 detection were analyzed with a fluorescence microscope (Zeiss, Axiophot, Germany). Histolab software (Microvision Instruments, Evry, France) was used to analyze and quantify the staining.

Quantitative analyses were performed in cortical, hippocampal and dentate neuroepithelia of brains from embryos from GD13 and fetuses from GD18 and in the DG of hippocampus from PND0 and PND5. At PND21, analyses were focused on the granular cell layer of the DG.

From each developmental stage, DU-exposed animals were compared with controls. We measured the BrdU-stained area $/ \mathrm{mm}^{2}$ on each structure in embryos GD13, fetuses GD18 and pups from PND0 and PND5. The density (number of BrdU-positive cells $/ \mathrm{mm}^{2}$ ) in the granular cell layer of DG of PND21 rats was analyzed and compared between control and DU-exposed groups. The number of fluorojade-positive cells and the number of cleaved caspase 3positive cells $/ \mathrm{mm}^{2}$ were quantified at all stages of DU exposure.

\subsection{Statistical analyses}

U concentrations in samples were compared between control and DU-exposed groups with one-way analysis of variance (ANOVA) followed by Tukey's test.

Body weights of neonatal and postnatal rats are presented as mean \pm standard deviation (SD) in Table 1. One-way ANOVA followed by Dunn's method or the Holm-Sidak method was used to compare the body weights of the control and exposed groups.

Analyses were performed on 5 animals from different litters per group for histological staining and immunochemistry. All results are graphically presented as means \pm SD. One-way ANOVA followed by Dunn's method or the Holm-Sidak method was used to compare the control and exposed groups.

Differences were considered statistically significant for $p<0.05$. All statistical analyses were performed using Sigmaplot

Table 1

Uranium concentration in kidneys of animals.

\begin{tabular}{|c|c|c|c|c|c|}
\hline & GD13 & GD18 & PND0 & PND5 & PND21 \\
\hline Control & $1.80 \pm 1.06$ & $2.45 \pm 0.53$ & $3.68 \pm 0.99$ & $4.32 \pm 2.17$ & $5.25 \pm 1.08$ \\
\hline DU40 & $34.47 \pm 14.81^{* * *}$ & $76.39 \pm 38.99^{* * *}$ & $68.77 \pm 32.39^{* * *}$ & $124.47 \pm 44.39^{* * *}$ & $142.29 \pm 57.50^{* * *}$ \\
\hline DU120 & $226.11 \pm 148.08^{* * *}$ & $152.90 \pm 51.72^{* * *}$ & $378.55 \pm 147.49^{* * *}$ & $555.07 \pm 157.32^{* * *}$ & $1722.16 \pm 577.74^{* * *}$ \\
\hline
\end{tabular}

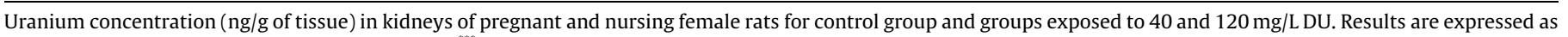
mean \pm SD and the level of significance was set at ${ }^{* * *} p<0.001$. DU: depleted uranium, GD: gestational day, PND: postnatal day. 
software (Systat software Inc., San Jose, Ca) by using standard deviation (SD).

\section{Results}

\subsection{General health parameters and uranium levels in exposed animals}

Throughout the exposure period, drinking water and food consumption were measured weekly and were similar in the DUexposed and control animals.

$U$ concentrations in the kidneys of exposed pregnant and nursing female rats were significantly higher than in control females when measured on GD13, GD18, PND0, PND5 and PND21 (Table 1). U levels in bodies of embryos from GD13, fetuses from GD18, pups from PND0 and PND5 and in the kidneys of PND21 rats are shown in Fig. 1. No significant accumulation of $U$ was observed in exposed embryos from GD13 and fetuses from GD18 compared with the control group. However, $U$ concentrations in the bodies of pups from PND0 and PND5 and in the kidneys of PND21 rats were significantly higher in exposed rats to 40 and $120 \mathrm{mg} / \mathrm{L}$ DU than in control animals $(p<0.001)$ (Fig. 1$)$.

The number of embryos, fetuses and new born pups was not modified after DU exposure. No change in body weight gains of pregnant females or of embryos from GD13 and fetuses from GD18 was observed after exposure to DU (data not shown). Body weights of neonatal and postnatal pups are summarized in Table 2. Analyses showed a significant decrease of body weight of newborn pups exposed to 40 and $120 \mathrm{mg} / \mathrm{L}$ DU compared with control animals. However, we observed a significant increase of body weight of PND5 pups exposed to 40 and $120 \mathrm{mg} / \mathrm{L} \mathrm{DU}$ and an increase of body weight of PND21 male rats exposed to $120 \mathrm{mg} / \mathrm{L}$ DU compared with control groups.

\subsection{Effects of DU on neurogenesis during prenatal brain development}

\subsubsection{Brain morphology}

We first used Nissl staining to study cell morphology and histological patterns of the brain after DU exposure. No major modification of morphology of the brain structures was observed in embryos from GD13 or fetuses from GD18 exposed to DU compared with control animals. We then focused on specific areas

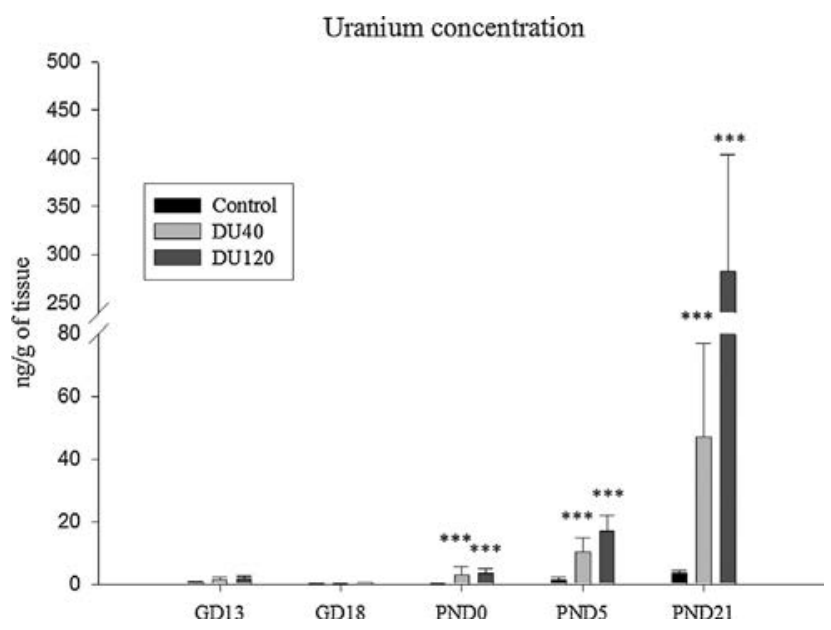

Fig. 1. Uranium concentration at prenatal and postnatal stages. Uranium concentration (ng/g of tissue) in embryos from GD13, fetuses from GD18, bodies of PND0 and PND5 pups and kidneys of PND21 rats in control and rats exposed to 40 and $120 \mathrm{mg} / \mathrm{L}$ DU. Asterisks indicate a significant difference between the exposed and control rats (one-way ANOVA, ${ }^{* * *} p<0.001$ ). GD: gestational day, PND: postnatal day, DU: depleted uranium.
Table 2

Body weight of animals.

\begin{tabular}{|c|c|c|c|}
\hline \multirow[t]{2}{*}{ Stages } & \multicolumn{3}{|l|}{ Weight (g) } \\
\hline & Control & DU40 & DU120 \\
\hline PND0 & $7.026 \pm 0.549$ & $6.482 \pm 0.553^{*}$ & $6.633 \pm 0.336^{*}$ \\
\hline PND5 & $9.686 \pm 1.563$ & $11.132 \pm 1.287^{*}$ & $10.632 \pm 1.736^{*}$ \\
\hline PND21 & $41.723 \pm 6.687$ & $38.820 \pm 6.670$ & $50.330 \pm 5.153^{*}$ \\
\hline
\end{tabular}

Body weight of pups and young adult rats at the end of the experiments. Results are expressed as mean \pm SD for control animals and animals exposed to 40 and $120 \mathrm{mg} / \mathrm{L}$ DU. The level of significance was set at ${ }^{*} p<0.05$. DU: Depleted uranium, PND: postnatal day.

of the telencephalon, and the cortical and hippocampal neuroepithelia of these embryos and fetuses and also the dentate neuroepithelium of fetuses. We compared lateral and medial levels of control and DU-exposed groups. In exposed embryos from GD13, the distribution and morphology of cell bodies in the cortical preplate (CPP), the sub-ventricular zone (SVZ) and the ventricular zone (VZ) of the cortical neuroepithelium were similar to those of control animals. Likewise, cell bodies in the intermediate zone (IZ), the SVZ and the VZ of the hippocampal neuroepithelium had a similar cell distribution and morphology in DU-exposed embryos and in control animals (Fig. 2A-C). No modification in the distribution and morphology of cell bodies was observed in exposed fetuses from GD18 in layer 1 (L1), the cortical plate (CP), cortical subplate (CSP), intermediate zone (IZ), SVZ or VZ of the cortical neuroepithelium, or in the intermediate zone (IZ), SVZ and $\mathrm{VZ}$ of the hippocampal and dentate neuroepithelia compared to control group (Fig. 3A-C).

\subsubsection{Cell death process}

Neural cell death and more specifically in cortical, hippocampal and dentate neuroepithelia were studied using fluorojade $C$ staining to identify dying neurons and cleaved caspase 3 antibody to stain apoptotic cells. Cells labeled with fluorojade C were similarly distributed in the SVZ of the cortical and hippocampal neuroepithelia in DU-exposed embryos from GD13 compared with controls. However, quantitative analysis showed a significant decrease in the number of fluorojade-positive cells only in the cortical neuroepithelium at the medial level of the brain at $120 \mathrm{mg} / \mathrm{L} \mathrm{DU}\left(\mathrm{CN}\right.$ : control $=3.70 \pm 1.60 \times 10^{-2} \mathrm{~mm}^{2}$, DU40 $=2.40 \pm 0.50 \times 10^{-2} \mathrm{~mm}^{2}$, DU120 $=1.78 \pm 0.58 \times 10^{-2} \mathrm{~mm}^{2}$, $p<0.01$ ) (Fig. 4A and B). Few cleaved caspase 3-positive cells with pyknotic nuclei were identified in the cortical and hippocampal neuroepithelia at GD13. In the lateral and medial levels of the brain, cleaved caspase 3-positive cells were located in the CPP and SVZ of the cortical neuroepithelium and in the IZ and SVZ of the hippocampal neuroepithelium. Distribution of cleaved caspase 3-positive cells was similar in the control and DU-exposed groups and no modification of their number was observed between control and exposed embryos (Fig. 4C and D).

Analysis of neuronal cell death in fetuses from GD18 showed that fluorojade-positive cells were observed in the CP and SVZ of the cortical neuroepithelium and in the IZ and SVZ of the hippocampal neuroepithelium. In fetuses exposed to $120 \mathrm{mg} / \mathrm{L}$ $\mathrm{DU}$, the number of fluorojade-labeled cells tended to decrease in the cortical and hippocampal neuroepithelia, but quantitative analyses showed a significant decrease only at the lateral level of the cortical neuroepithelium at $120 \mathrm{mg} / \mathrm{L}$ DU (CN: control $=3.39 \pm 1.11 \times 10^{-2} \mathrm{~mm}^{2}, \quad$ DU $40=4.81 \pm 1.72 \times 10^{-2} \mathrm{~mm}^{2}$, DU120 $\left.=1.96 \pm 1.54 \times 10^{-2} \mathrm{~mm}^{2}, p<0.05\right)$ (Fig. 4E and F). Like in the embryos, few cleaved caspase 3-positive cells with pyknotic nuclei were observed in the cortical and hippocampal neuroepithelia in the fetuses. Cleaved caspase 3-positive cells were located in the CPP 

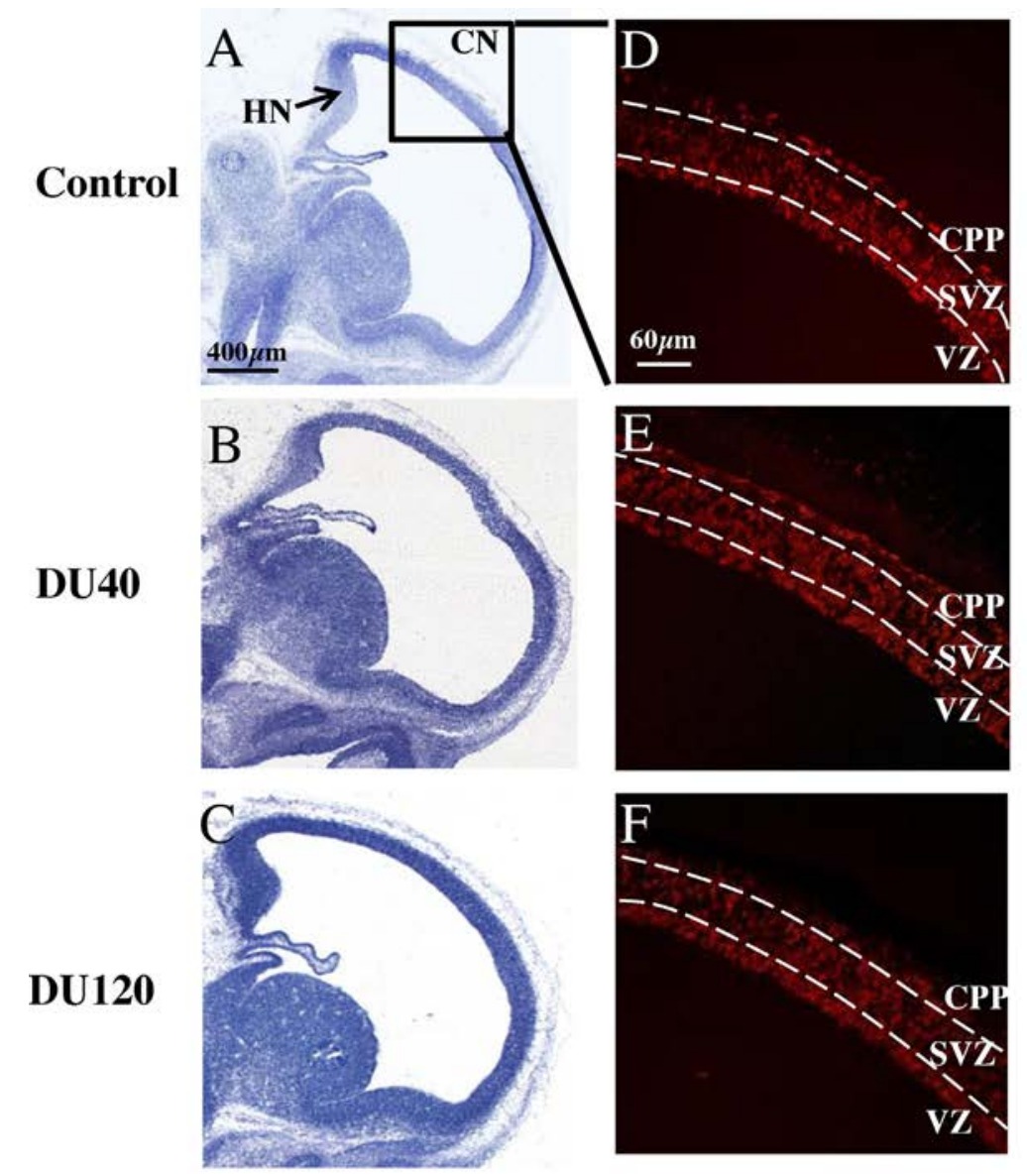

\section{BrdU-positive area/total area}

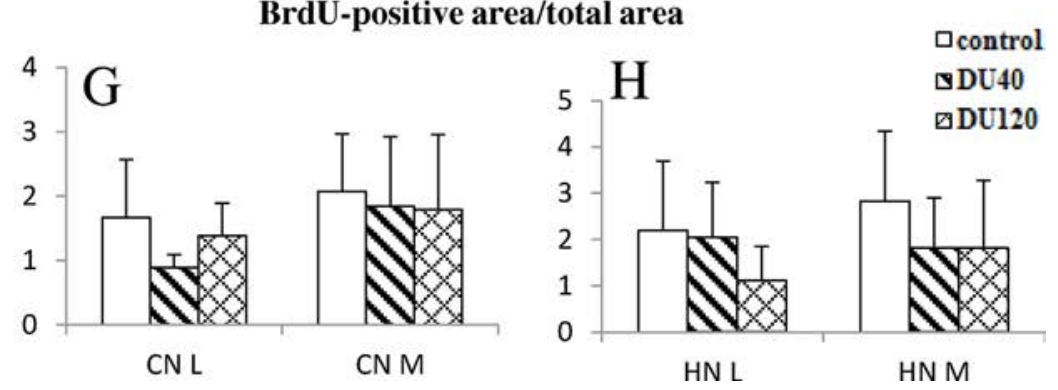

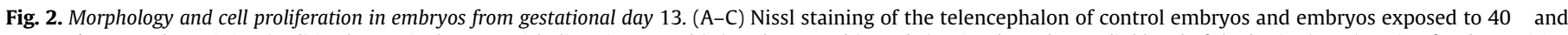

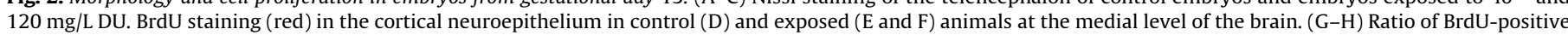

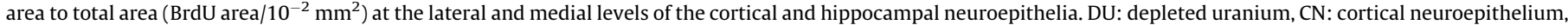
HN: hippocampal neuroepithelium, VZ: ventricular zone, SVZ: sub-ventricular zone, CPP: cortical pre-plate; L: lateral, M: median.

and SVZ of the cortical neuroepithelium and the IZ and SVZ of the hippocampal neuroepithelium for each exposure group and their number was not modified by $U$ exposure (Fig. $4 \mathrm{G}$ and $\mathrm{H}$ ).

\subsubsection{Cell proliferation process}

We investigated cell proliferation using BrdU incorporation into nuclei of dividing cells during the $S$ phase of the cell cycle. At GD13, BrdU immunolabeling for control embryos was intense and distributed throughout the thickness of the cortical and hippocampal neuroepithelia. Neuronal nuclei with abundant BrdU immunoreactivity were observed in the CPP of the cortical neuroepithelium and in the IZ of the hippocampal neuroepithelium and in the SVZ and VZ of both neuroepithelia (Fig. 2D-F). A similar pattern of BrdU immunolabeling was identified in the cortical and hippocampal neuroepithelia at the lateral and medial levels of embryos exposed to $40 \mathrm{mg} / \mathrm{L}$ and $120 \mathrm{mg} / \mathrm{L}$ DU (Fig. 2D-F). Quantitative analyses of the BrdU-positive area to total area ratio showed no significant change between exposed and control animals (Fig. 2G and $\mathrm{H}$ ).

In control fetuses from GD18, neuronal nuclei with abundant BrdU immunoreactivity were numerous and principally localized in the VZ and SVZ of the cortical, hippocampal and dentate neuroepithelia (Fig. 3D). No significant change in BrdU-positive staining was observed in the cortical and hippocampal neuroepithelia of fetuses exposed to $40 \mathrm{mg} / \mathrm{L}$ and $120 \mathrm{mg} / \mathrm{L} \mathrm{DU}$ (Fig. 3E and F). In contrast, in the area of the dentate neuroepithelium, quantitative analysis revealed a significant increase of BrdUpositive labeling in fetuses exposed to $120 \mathrm{mg} / \mathrm{L}$ DU (control $=0.51 \pm 0.41 \times 10^{-2} \mathrm{~mm}^{2}, \quad$ DU $40=0.82 \pm 0.31 \times 10^{-2} \mathrm{~mm}^{2}$, DU120 $=1.77 \pm 0.63 \times 10^{-2} \mathrm{~mm}^{2}, p<0.01$ ) (Fig. $3 \mathrm{G}$ and $\mathrm{H}$ ). 

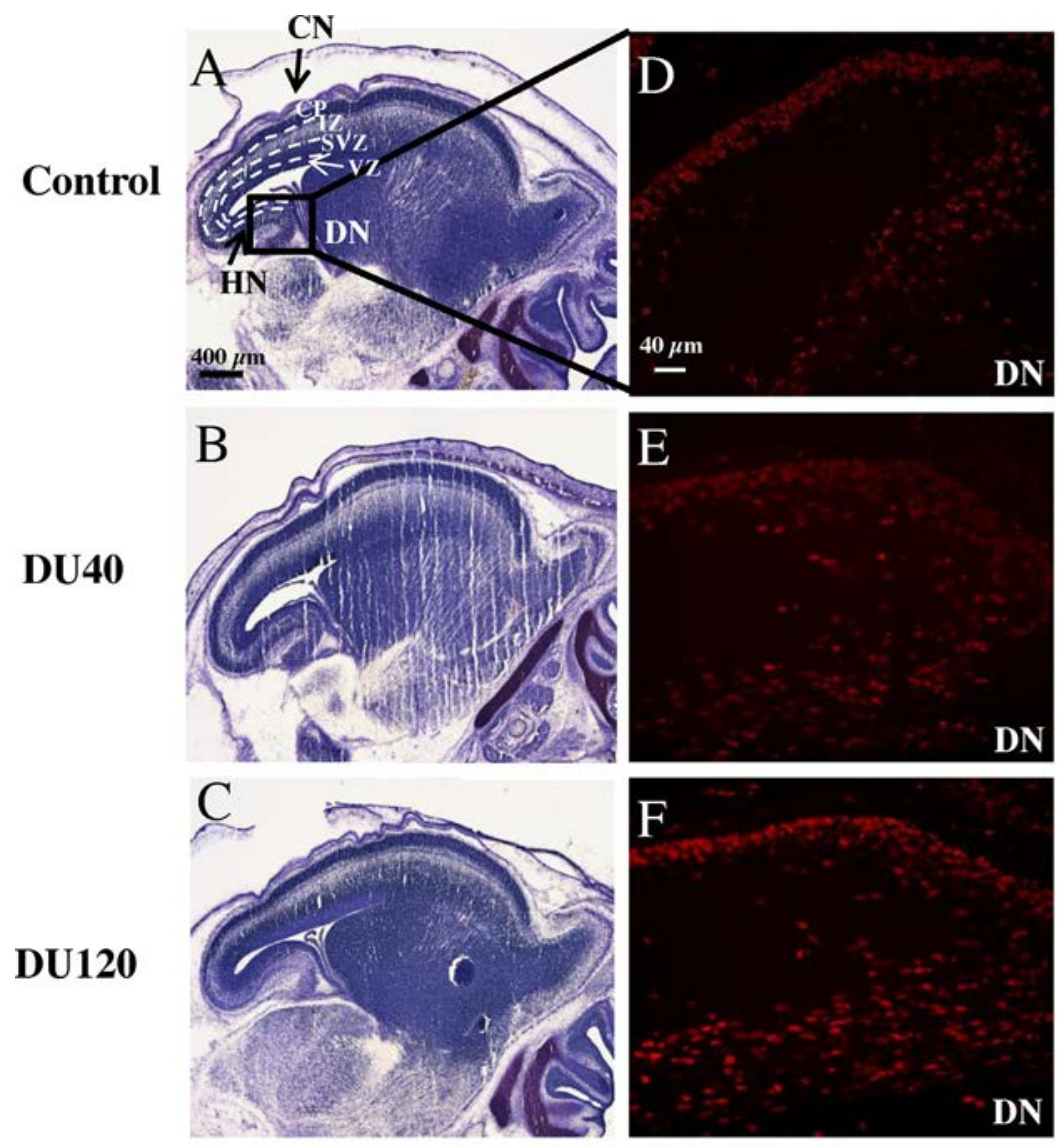

BrdU-positive area/total area

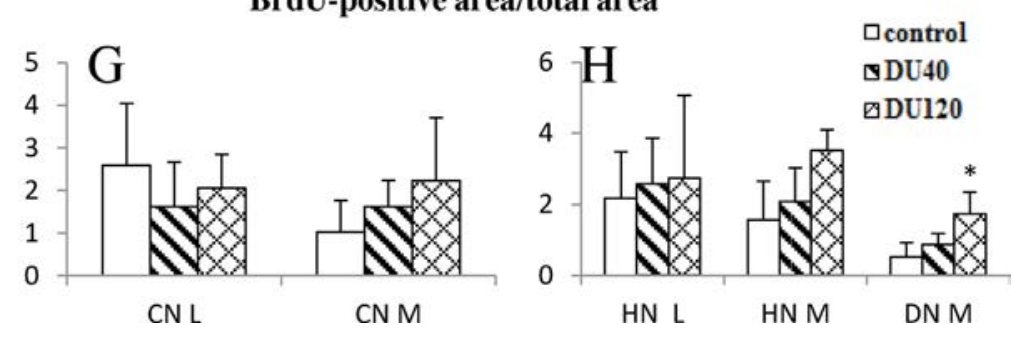

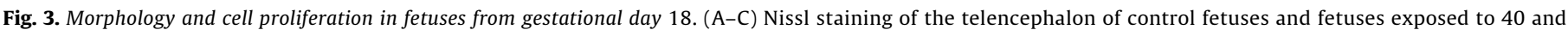

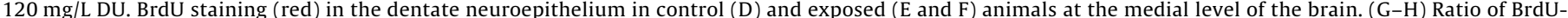

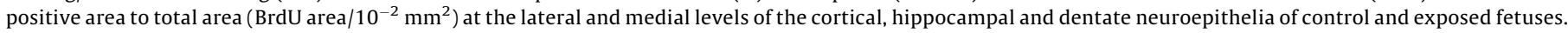

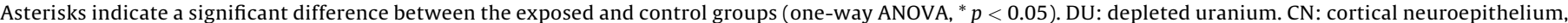

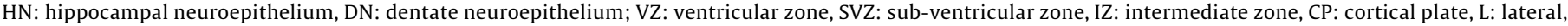
M: median.

\subsection{Effects of DU on neurogenesis during neonatal and postnatal brain development}

\subsubsection{Hippocampal morphology}

In rodents, most granular cells are produced after birth and the DG grew postnatally to maturity one month after birth. Our analyses of the DG were therefore conducted at four levels of the hippocampus from neonatal stage (PND0, PND5) and postnatal stage (PND21).

The hilus, the tertiary dentate matrix and the inner granule cell layer (GCL) had similar primitive features in exposed neonatal pups compared with controls (Figs. 5A-C and 6A-C), as described by Altman and Bayer (1990). Likewise, the morphology of the GCL, the hilus $(\mathrm{H})$, and the molecular layer $(\mathrm{ML})$ of exposed PND21 rats was similar to that of control animals (Fig. 7A-C).

\subsubsection{Cell death process}

The cell death process, specifically in the DG, showed that fluorojade-positive cells were distributed in the GCL and in the $\mathrm{H}$ of the DG in both DU-exposed and control neonatal groups. The number of labeled cells was significantly increased in the DG in pups from both PND0 and PND5 exposed to $120 \mathrm{mg} / \mathrm{L}$ DU, as follows: PND0: $\quad$ control $=1.21 \pm 0.15 \times 10^{-2} \mathrm{~mm}^{2}, \quad$ DU40 $=1.31 \pm$ $0.15 \times 10^{-2} \mathrm{~mm}^{2}, \quad$ DU120 $=2.01 \pm 0.28 \times 10^{-2} \mathrm{~mm}^{2}, \quad p<0.01$ and PND5: $\quad$ control $=2.24 \pm 0.54 \times 10^{-2} \mathrm{~mm}^{2}, \quad$ DU40 $=2.64 \pm 0.87 \times$ $10^{-2} \mathrm{~mm}^{2}$, DU120 $=3.99 \pm 1.04 \times 10^{-2} \mathrm{~mm}^{2}, p<0.05$ (Fig. $8 \mathrm{~A}$ and C). In addition, cleaved caspase 3 -positive cells with pyknotic nuclei were identified in the GCL and $\mathrm{H}$ of control and DU-exposed animals. The number of caspase 3-positive cells was similar in control and DU-exposed newborn pups, but was significantly increased only in PND5 DU-exposed pups at DU120, as follows: control: 


\section{Fluorojade-positive cell number/total area at GD13}
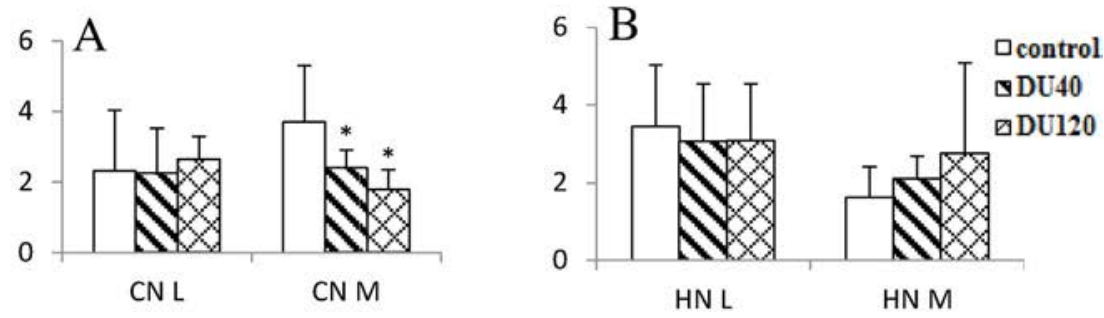

\section{Cleaved caspase 3-positive cell number/total area at GD13}
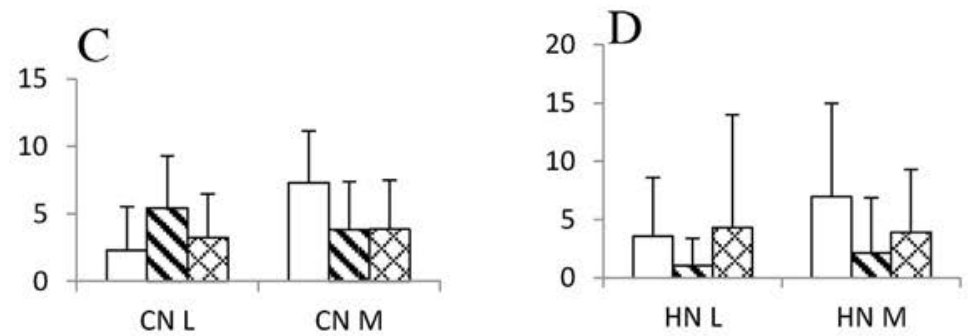

\section{Fluorojade-positive cell number/total area at GD18}
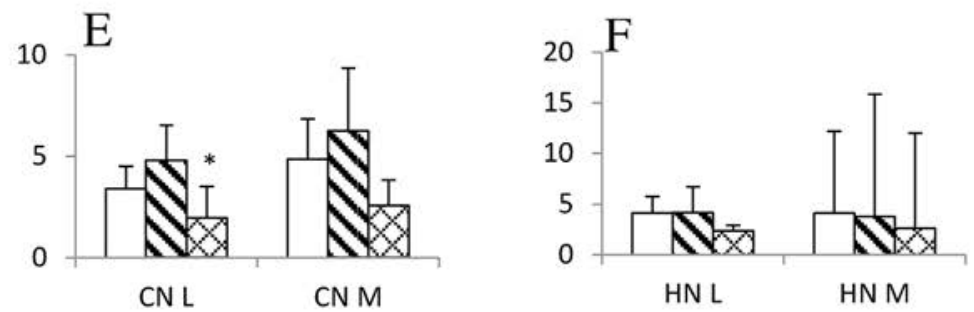

\section{Cleaved caspase 3-positive cell number/total area at GD18}
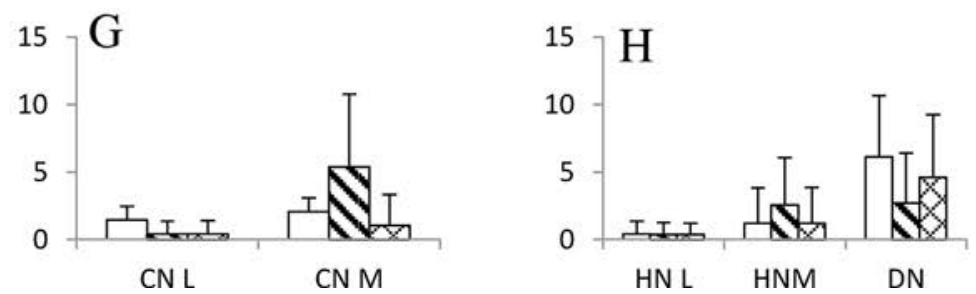

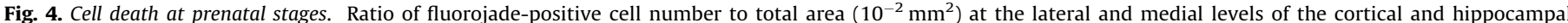

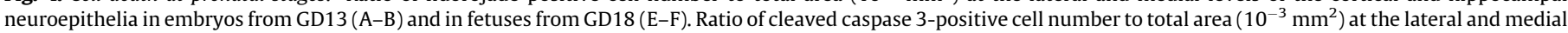

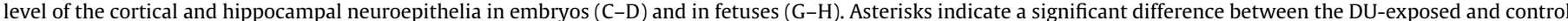

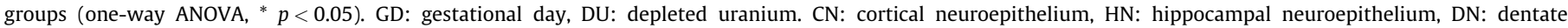
neuroepithelium, L: lateral, M: median.

$0.59 \pm 0.85 \times 10^{-3} \mathrm{~mm}^{2}$, DU40 $=1.13 \pm 0.90 \times 10^{-3} \mathrm{~mm}^{2}$, DU120 $=$ $2.96 \pm 1.87 \times 10^{-3} \mathrm{~mm}^{2},{ }^{*} p<0.05$ (Fig. 8B and D).

In the DG of PND21 rats, fluorojade assay showed few labeled cells in the GCL in controls as well as in DU-exposed rats. Quantitative analyses of fluorojade-positive cells did not show any significant difference in DU-exposed compared with control groups (Fig. 8E). Very few activated caspase-positive cells with pyknotic nuclei were stained in the GCL and no modification was observed in the number of positive cells between exposed and control animals (Fig. 8F).

\subsubsection{Cell proliferation process}

In the hippocampus of control animals, the BrdU-positive nuclei at PND0 and PND5 were principally round in shape and were distributed in the GCL and in the H of the DG (Figs. Fig. 5 and 6D). Quantitative analysis showed no modification of BrdU staining in the DG between control and DU-exposed groups (Figs. 5D-G and $6 D-G)$. In the DG of PND 21 rats, round BrdU-positive nuclei were principally located in the GCL and subgranular zone (SGZ) in control and in DU-exposed animals (Fig. 7D-F). Whereas no change was observed for the DU40-exposed group, quantitative analyses 

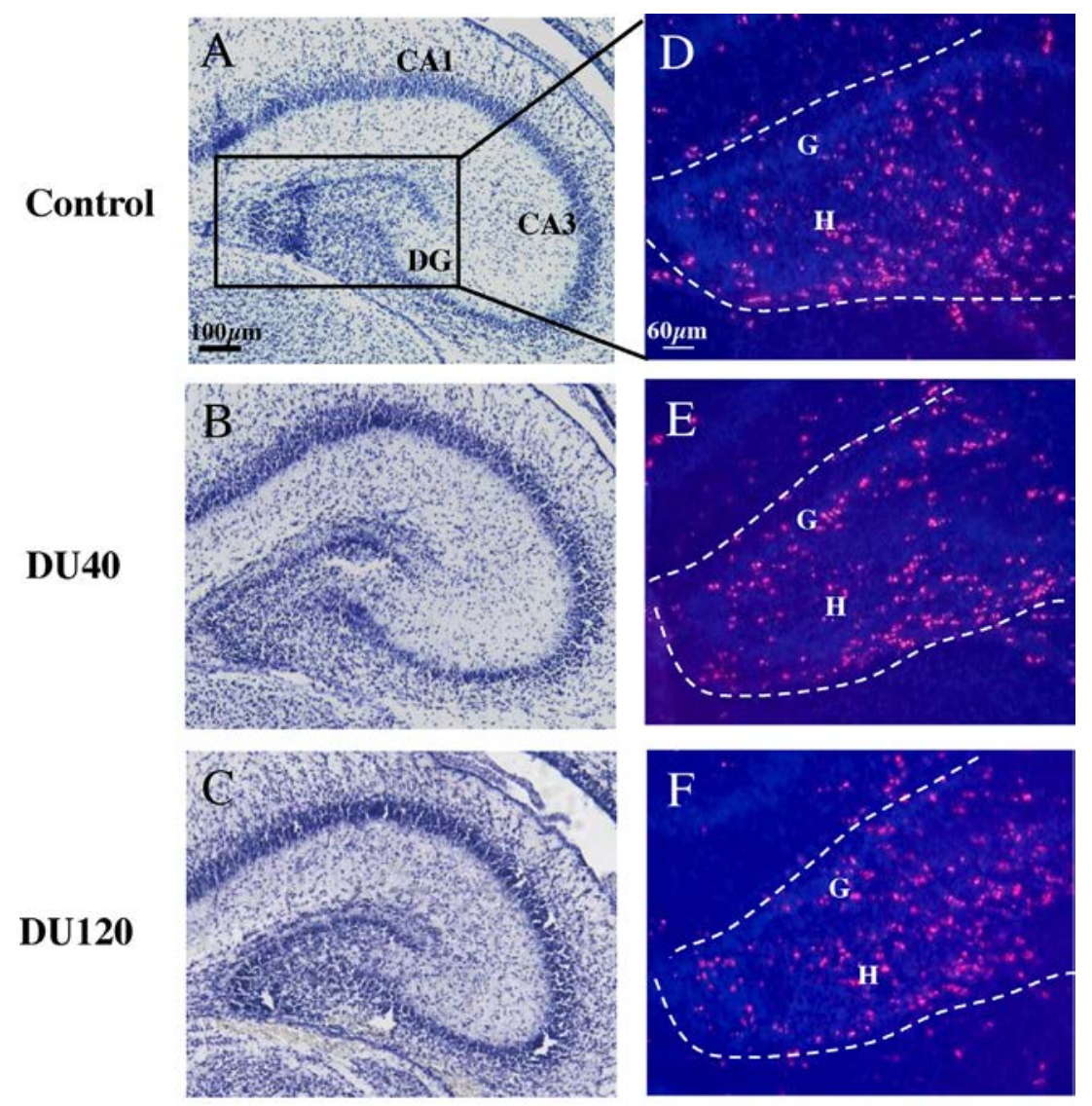

BrdU-positive area/total area

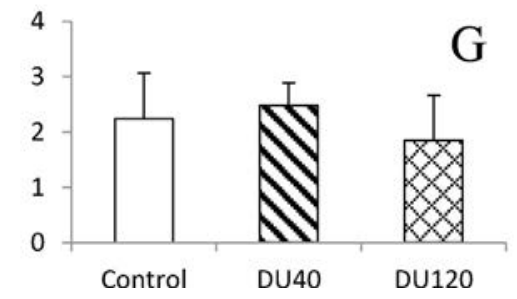

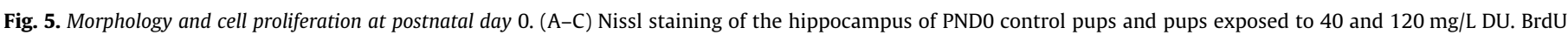

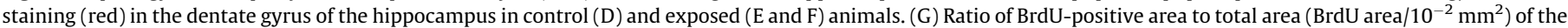
dentate gyrus of pups. PND: postnatal day, DU: depleted uranium, H: hilus, G: granular zone, CA: Ammon's horn, DG: dentate gyrus.

showed a significant decrease in the number of BrdU-positive cells in the GCL of young rats exposed to $120 \mathrm{mg} / \mathrm{L}$ DU (PND21: control $=3.62 \pm 1.47$, DU40 $=2.54 \pm 0.71$, DU120 $=1.85 \pm 0.45, p<0.05)$ (Fig. 7G).

\section{Discussion}

Humans are continuously exposed to neurotoxic compounds from early life to adulthood. The central nervous system develops over a long period of time extending from embryogenesis through puberty, including vulnerable periods when normal development can be modified. Thus, exposure to heavy metals like $U$ during these critical periods could affect brain development and have an impact on cognitive functions (Desi et al., 1998; Lehotzky et al., 1990). We demonstrate here for the first time that chronic internal exposure to DU can disturb the processes of neurogenesis during brain development.

The concentrations of DU measured in the kidney of the pregnant rats and in the bodies or kidneys of embryos, fetuses and pups confirmed that animals were well exposed. We observed no accumulation of DU in embryos or fetuses from GD13 or GD18, respectively. However, from PND0 to PND21, a dose- and time-dependent accumulation of DU was clearly demonstrated. Thus, our data suggest that embryos and fetuses did not accumulate DU until gestational day 18, as previously reported (Sanchez et al., 2006), but that DU might accumulate in the last days of gestation until birth., It has been show that U was detected in the placenta as well as in fetuses after exposure at high doses of U (Domingo, 2001; Sanchez et al., 2006). The accumulation of DU at postnatal stages strongly suggests that pups were exposed via their mothers' milk, as demonstrated in humans (Wappelhorst et al., 2002). In addition, the very high quantity of $U$ in the kidneys of PND 21 rats could be explained by the fact that the animals began to drink water directly from the feeding bottle. Like our study, Sanchez et al. (2006) measured a high quantity of $U$ in kidney of pups exposed in utero until PND30 but did not detect $U$ quantity in the brain of pups even at the highest doses of $U$. 

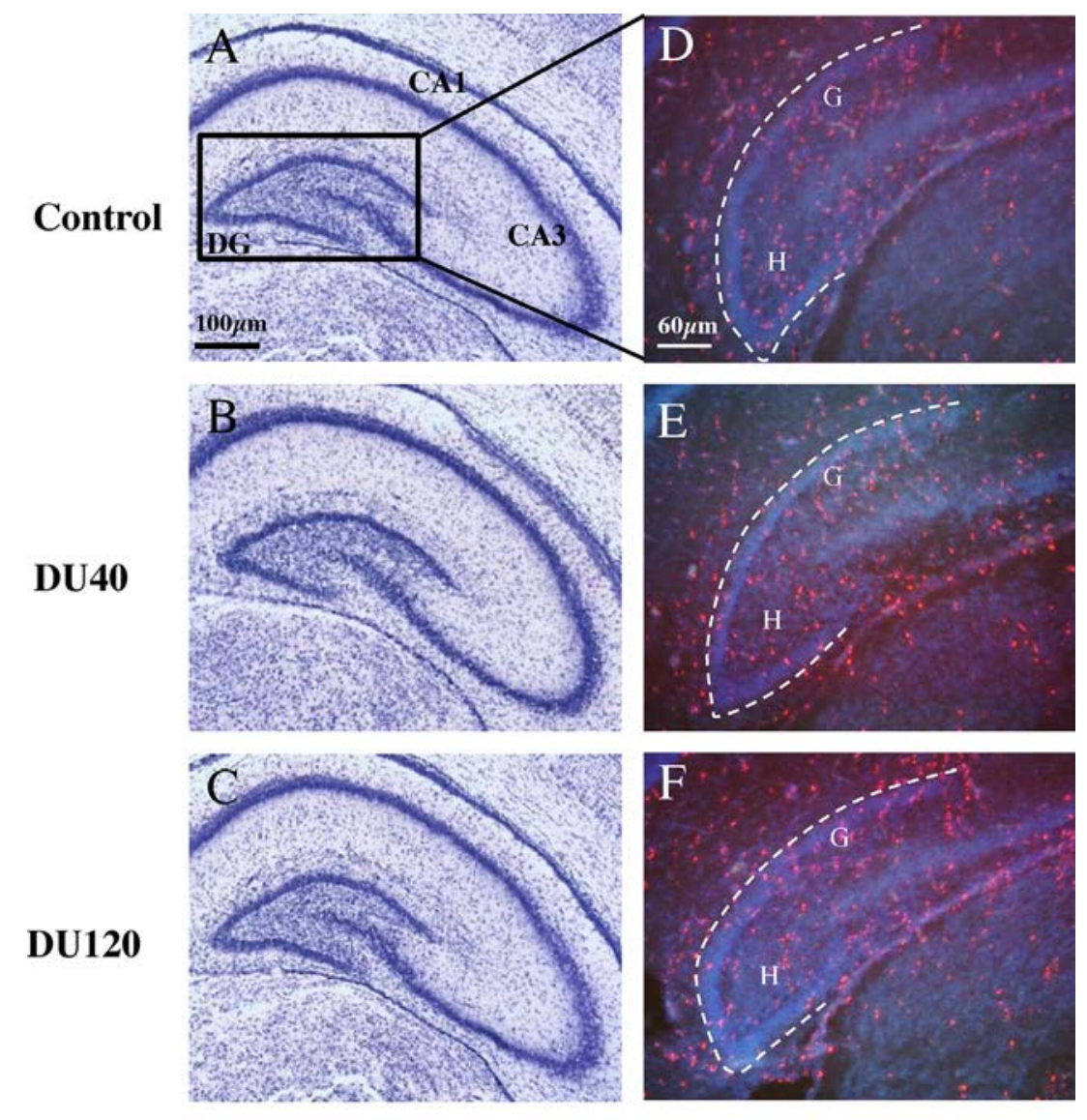

BrdU-positive area/total area

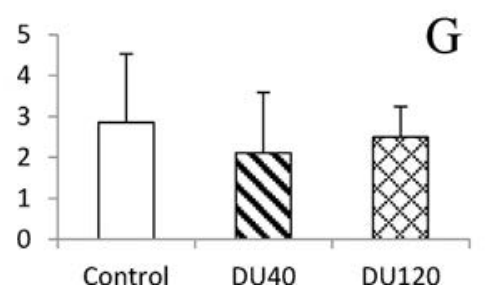

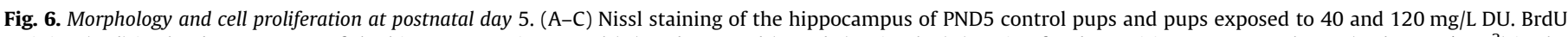

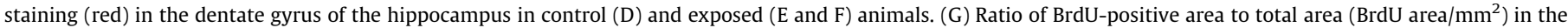
dentate gyrus of PND5 rats. PND: postnatal day, DU: depleted uranium, H: hilus, G: granular zone, CA: Ammon's horn, DG: dentate gyrus.

Prenatal exposure to 40 and $120 \mathrm{mg} / \mathrm{L}$ DU did not affect maternal weight gain during pregnancy, litter size or the body weight of embryos and fetuses. Contrary to our results, previous studies have shown a decrease in maternal body weight gain and a decrease in fetal body weight after subcutaneous injection of $U$ or after ingestion of high doses of $U$ during gestation (Domingo, 2001 ). These discrepancies could be explained by differences in the contamination protocol used and by the $U$ concentration administered. On the other hand, our data showed that DU altered body weight after birth, as previously demonstrated (Domingo, 2001; Sanchez et al., 2006).

We explored brain development at GD13 and GD18 in three structures of the telencephalon, the cortical, hippocampal and dentate neuroepithelia. In rodents, the embryonic stage during GD13 is the most intense proliferation stage and at fetal stage GD18, cortical cell layers begin to appear (Abdel-Mannan et al., 2008). Hippocampal regions begin to form in fetuses from GD15 to GD21 and the dentate granular cells appear mostly in fetuses after
GD18 (Bayer, 1980). As a consequence, altered neurogenesis, especially neuronal cell death and cell proliferation at these time points, could affect brain development.

Our results showed a decrease in cell death by fluorojade staining in the cortical neuroepithelium of embryos exposed from $40 \mathrm{mg} / \mathrm{L}$ DU and fetuses exposed to $120 \mathrm{mg} / \mathrm{L}$ DU. Nevertheless, no change in pyknotic cell number associated with cleaved caspase 3 staining was observed in exposed animals. These results suggest that other pathways than apoptosis could be affected by DU toxicity, like necrosis (Oppenheim, 1991). In this study, we demonstrated for the first time that in utero contamination with DU causes an imbalance of the cell death process during prenatal brain development.

Cell proliferation investigated by BrdU labeling was not modified in the cortical and hippocampal neuroepithelia of DUexposed embryos from GD13 and fetuses from GD18. However, the density of dividing cells increased in the dentate neuroepithelium of fetuses exposed to DU at the highest dose. Consistent with 

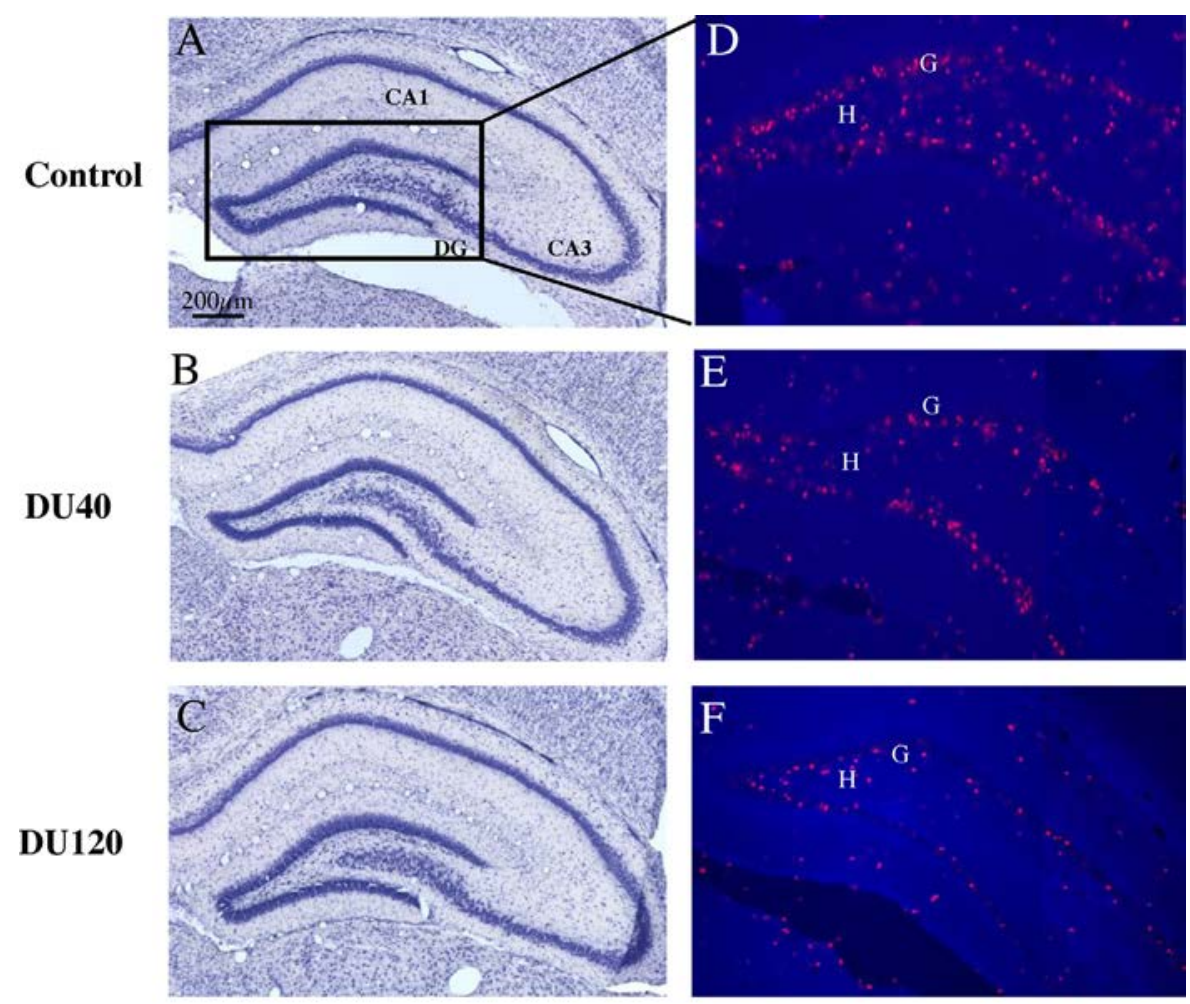

BrdU-positive cells number/ total area

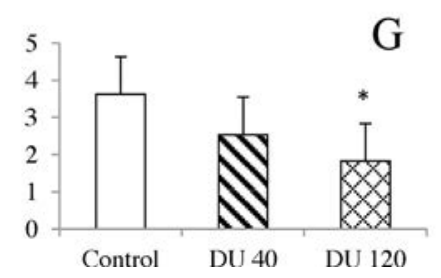

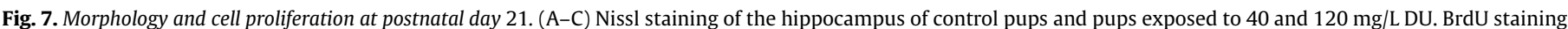

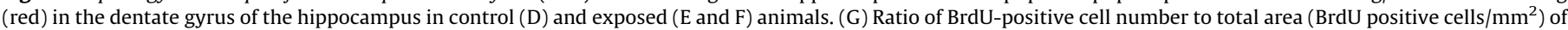

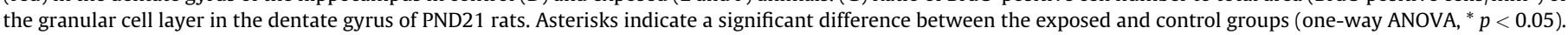
PND: postnatal day, DU: depleted uranium, H: hilus, G: granular cell layer, CA: Ammon's horn, DG: dentate gyrus.

current knowledge about the cell cycle of cortical precursor cells at this time of development, only neuronal progenitors were labeled when BrdU was injected $4 \mathrm{~h}$ before sacrifice (Calegari et al., 2005). Our results suggest that DU may act on cell proliferation by intensifying the production of dividing neural progenitors specifically in the dentate neuroepithelium during development.

Despite these confined changes in cell death pathways and cell proliferation, no major organogenesis or developmental disturbance was observed in the telencephalon, as seen in the layer organization. It has been reported that $U$ induces more brain malformations and developmental variations in fetuses, such as exencephaly at high doses (Domingo, 2001). In our experimental conditions, these types of malformations were never observed. Nevertheless, the U-induced alterations in neurogenesis that we observed prenatally could impact subsequent postnatal brain development.

We then focused on the development of the hippocampus after birth until weaning. At birth, the CA1, CA2 and CA3 regions are well organized in layers. However, the DG is immature and $85 \%$ of cells will be generated between PND0 and PND21 (Altman and Bayer, 1990). Cell death and cell proliferation were thus investigated in the DG during neonatal and postnatal development.

We observed an increase of cell death by fluorojade staining in the dentate gyrus of PND0 and PND5 exposed pups associated with a significant increase of apoptotic cell number in PND5 exposed pups. At PND0, our data show also an increase of apoptotic cell number in exposed pups but it was not significant. This increase of the cell death has been observed only at the highest dose of DU exposure. Therefore, our results suggest that apoptosis seems to be one of the pathways of cell death affected by DU, but it could also disturb cell death by acting on different pathways during postnatal development (Oppenheim, 1991). Our results suggest also that DU affects cell death pathways only at early stage of development since no modification has been observed at PND21.

Our results on cell proliferation showed no change in BrdU labeling in the DG of new born pups and pups exposed until PND5. However, at later postnatal stage, the number of dividing cells was diminished in the GCL and the SGZ in the DG exposed to the highest dose of DU. During later development of the DG, the proliferative cells become confined to the SGZ. PND21 is thus a transition stage between developmental and young adult periods and the SGZ becomes the granule cells production of the adult neurogenic zone. Based on these data, our results suggest that DU could cause a decrease in dividing cells in the DG of young adult rats exposed to $U$ during gestation and weaning.

Despite these alterations, the development of the hippocampus did not appear to be disrupted, as seen by the well organization of the layers of the DG at PND21. It is well known that neurogenesis in 
PND0

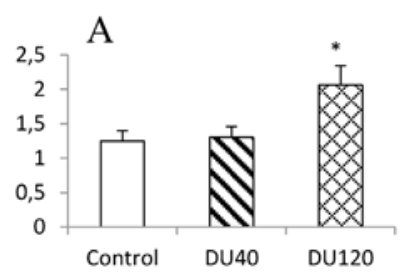

PND5

$\mathrm{C}$

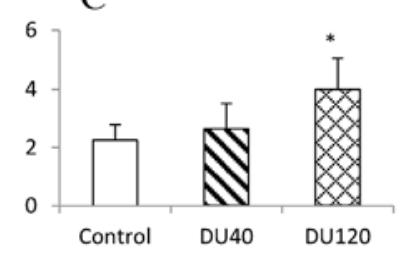

PND21

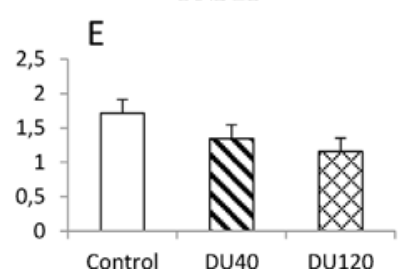

PND0
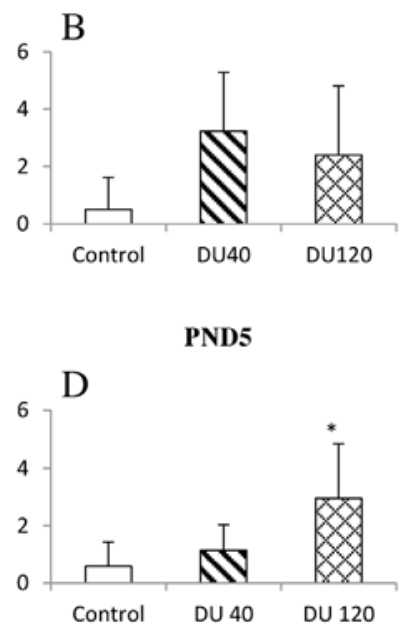

PND21

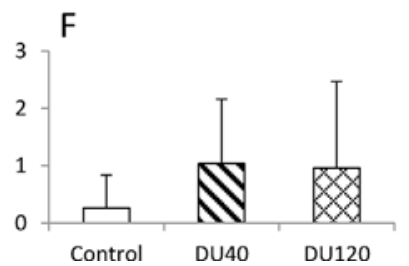

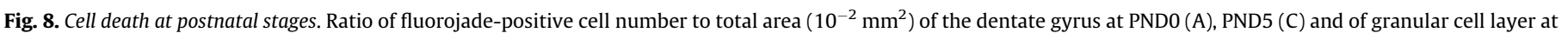

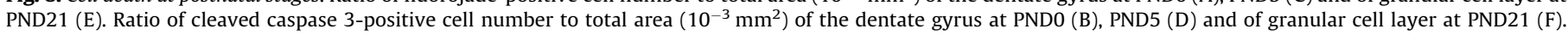
Asterisks indicate a significant difference between the exposed and control groups (one-way ANOVA, ${ }^{*} p<0.05$ ). PND: postnatal day, DU: depleted uranium.

the hippocampus represents a form of synaptic plasticity in the adult brain that is crucial in learning and memory (Deng et al., 2010). The decrease of new born cells that we observed in the DG at PND21 could thus impair synaptic plasticity and might cause cognitive dysfunctions in adulthood. No study is available about the effect of DU on cognitive functions after exposure during prenatal development. Only two studies have shown that exposure to DU from birth to 2 months impairs object recognition memory and causes a decrease of locomotor activity and an increase of anxiety (Lestaevel et al., 2013, 2015), that could be correlated with a change in neurogenesis.

The effects of the chemical toxicity of $U$ appear similar to those of other heavy metals, which are known to cause behavioral disorders in offspring after exposure during brain development (Desi et al., 1998). The exact mechanisms by which heavy metals alter behavior are unknown. Nonetheless, exposure to lead from gestation to adult life decreased the proliferation of new born cells in the DG (Verina et al., 2007), results similar to ours. Lead exposure from birth to PND30 also reduced generation of new born cells in the DG in 3-month-old rats (Jaako-Movits et al., 2005). In addition, an increase in the number of apoptotic cells was also seen in the cortex and hippocampus of neonatal mouse brain (Dribben et al., 2011) and in the hippocampus of PND30 rats after lead exposure (Liu et al., 2010). Finally, a direct correlation between behavior disorders and neurogenesis has been demonstrated in a developmental zebrafish model but not in rodent (Dou and Zhang, 2011). In the mammalian brain, the complexity of the molecular pathways underlying neurogenesis means that there are various targets that might be impacted by DU exposure. We have shown that DU exposure during brain development results in some disturbances in cell death and in cell proliferation. A modification of these two processes could have an impact on the subsequent steps of neurogenesis, as already shown for heavy metals (JaakoMovits et al., 2005; Verina et al., 2007).

\section{Conclusion}

In conclusion, our results are the first to show that DU exposure during gestation and lactation could cause localized alterations in neurogenesis at specific times and mainly at the highest dose. We show that DU did not accumulate until GD18 in the fetuses, suggesting that it is DU from the pregnant rats that could indirectly affect neurogenesis. In contrast, the quantity of DU found in neonatal and postnatal pups could directly cause observed effects. In addition, our results suggest that the effects are opposed between prenatal and postnatal development. Indeed, whereas DU seems to increase cell proliferation in the dentate neuroepithelium and decrease the cell death pathway throughout prenatal development, it causes a decrease of cell proliferation in the DG and increase of cell death pathway during postnatal development. Even though these modifications do not lead to major morphological changes in the development of brain structures, they could have an impact on the next steps of neurogenesis as neuronal differentiation, migration and synaptic integrity in neural networks and might disturbed cerebral functions in adulthood. Most of epidemiologic studies have been performed on adults but long term consequences of $U$ exposure on sensitive populations are still unknown. Our data show that brain development is sensitive to DU exposure. The release of $U$ into the environment could present a threat to human health, particularly for pregnant women and children who represent a more vulnerable population. 


\section{Funding information}

This study was part of the ENVIRHOM research program supported by the Institute for Radioprotection and Nuclear Safety (IRSN) and European DoReMi program (Low Dose Research towards Multidisciplinary integration).

\section{Conflict of interest statement}

The authors declare that there is no conflict of interest.

\section{Acknowledgements}

The authors thank Jean-Marc Bertho for advice and Frederic Voyer, Thierry Loiseau and Jean-Michel Guischet for animal care.

\section{References}

Abdel-Mannan, O., Cheung, A.F., Molnar, Z., 2008. Evolution of cortical neurogenesis. Brain Res. Bull. 75 (2-4), 398-404.

Altman, J., Bayer, S.A., 1990. Migration and distribution of two populations of hippocampal granule cell precursors during the perinatal and postnatal periods. J. Comp. Neurol. 301 (3), 365-381.

ATSDR, 2013. Toxicological Profile for Uranium. Public Health Service, Atlanta, GA.

Bayer, S.A., 1980. Development of the hippocampal region in the rat. II. Morphogenesis during embryonic and early postnatal life. J. Comp. Neurol. 190 (1), 115-134.

Bensoussan, H., Grancolas, L., Dhieux-Lestaevel, B., Delissen, O., Vacher, C.M., Dublineau, I., Voisin, P., Gourmelon, P., Taouis, M., Lestaevel, P., 2009. Heavy metal uranium affects the brain cholinergic system in rat following subchronic and chronic exposure. Toxicology 261 (1-2), 59-67.

Briner, W., 2010. The toxicity of depleted uranium. Int. J. Environ. Res. Public Health 7 (1), 303-313.

Briner, W., Abboud, B., 2002. Behavior of juvenile mice chronically exposed to depleted uranium. In: Khassanova, L., Collery, P.H., Maymard, I., Khassanova, Z., Etienne, J.C. (Eds.), Metal Ions in Biology and Medicine. John Libby Eurotext, Paris, pp. 353-356.

Briner, W., Davis, D., 2002. Lipid oxidation and behavior are correlated in depleted uranium exposed mice. In: Khassanova, L., Collery, P., Maymard, I., Khassanova, Z., Etienne, J.C. (Eds.), Metal Ions in Biology and Medicine, vol. 7. John Libby Eurotext, Paris, pp. 59-63.

Briner, W., Murray, J., 2005. Effects of short-term and long-term depleted uranium exposure on open-field behavior and brain lipid oxidation in rats. Neurotoxicol. Teratol. 27 (1), 135-144.

Bussy, C., Lestaevel, P., Dhieux, B., Amourette, C., Paquet, F., Gourmelon, P., Houpert, P., 2006. Chronic ingestion of uranyl nitrate perturbs acetylcholinesterase activity and monoamine metabolism in male rat brain. Neurotoxicology 27 (2), 245-252.

Calegari, F., Haubensak, W., Haffner, C., Huttner, W.B., 2005. Selective lengthening of the cell cycle in the neurogenic subpopulation of neural progenitor cells during mouse brain development. J. Neurosci. 25 (28), 6533-6538 (the official journal of the Society for Neuroscience).

Chow, E.S., Hui, M.N., Lin, C.C., Cheng, S.H., 2008. Cadmium inhibits neurogenesis in zebrafish embryonic brain development. Aquat. Toxicol. 87 (3), 157-169.

Deng, W., Aimone, J.B., Gage, F.H., 2010. New neurons and new memories: how does adult hippocampal neurogenesis affect learning and memory? Nat. Rev. Neurosci. 11 (5), 339-350.

Desi, I., Nagymajtenyi, L., Schulz, H., 1998. Behavioural and neurotoxicological changes caused by cadmium treatment of rats during development. J. Appl. Toxicol.: JAT 18 (1), 63-70.

Domingo, J.L., Llobet, J.M., Tomas, J.M., Corbella, J., 1987. Acute toxicity of uranium in rats and mice. Bull. Environ. Contam. Toxicol. 39 (1), 168-174.

Domingo, J.L., 2001. Reproductive and developmental toxicity of natural and depleted uranium: a review. Reprod. Toxicol. 15 (6), 603-609.

Dou, C., Zhang, J., 2011. Effects of lead on neurogenesis during zebrafish embryonic brain development. J. Hazard. Mater. 194, 277-282.

Dribben, W.H., Creeley, C.E., Farber, N., 2011. Low-level lead exposure triggers neuronal apoptosis in the developing mouse brain. Neurotoxicol. Teratol. 33 (4), 473-480.
Gotz, M., Huttner, W.B., 2005. The cell biology of neurogenesis. Nat. Rev. Mol. Cell Biol. 6 (10), 777-788.

Houpert, P., Lestaevel, P., Bussy, C., Paquet, F., Gourmelon, P., 2005. Enriched but not depleted uranium affects central nervous system in long-term exposed rat. Neurotoxicology 26 (6), 1015-1020.

Houpert, P., Frelon, S., Lestaevel, P., Bussy, C., Gourmelon, P., Paquet, F., 2007. Parental exposure to enriched uranium induced delayed hyperactivity in rat offspring. Neurotoxicology 28 (1), 108-113.

Howland, J.W., 1948. Comprehensive summary of the pharmacology and toxicology of uranium compounds; studies on human exposures to uranium compounds. At. Energy Biophys. Biol. Med. 1 (5), 174.

Jaako-Movits, K., Zharkovsky, T., Romantchik, O., Jurgenson, M., Merisalu, E., Heidmets, L.T., Zharkovsky, A., 2005. Developmental lead exposure impairs contextual fear conditioning and reduces adult hippocampal neurogenesis in the rat brain. Int. J. Dev. Neurosci. 23 (7), 627-635 (the official journal of the International Society for Developmental Neuroscience).

Lehotzky, K., Ungvary, G., Polinak, D., Kiss, A., 1990. Behavioral deficits due to prenatal exposure to cadmium chloride in CFY rat pups. Neurotoxicol. Teratol. 12 (2), 169-172.

Lemercier, V., Millot, X., Ansoborlo, E., Menetrier, F., Flury-Herard, A., Rousselle, C., Scherrmann, J.M., 2003. Study of uranium transfer across the blood-brain barrier. Radiat. Prot. Dosimetry 105 (1-4), 243-245.

Lestaevel, P., Bensoussan, H., Dhieux, B., Delissen, O., Vacher, C.M., Dublineau, I. Voisin, P., Taouis, M., 2013. Cerebral cortex and hippocampus respond differently after post-natal exposure to uranium. J. Toxicol. Sci. 38 (5), $803-$ 811.

Lestaevel, P., Bussy, C., Paquet, F., Dhieux, B., Clarencon, D., Houpert, P., Gourmelon, P., 2005a. Changes in sleep-wake cycle after chronic exposure to uranium in rats. Neurotoxicol. Teratol. 27 (6), 835-840.

Lestaevel, P., Dhieux, B., Delissen, O., Benderitter, M., Aigueperse, J., 2015. Uranium modifies or not behavior and antioxidant status in the hippocampus of rats exposed since birth. J. Toxicol. Sci. 40 (1), 99-107.

Lestaevel, P., Houpert, P., Bussy, C., Dhieux, B., Gourmelon, P., Paquet, F., 2005b. The brain is a target organ after acute exposure to depleted uranium. Toxicology 212 (2-3), 219-226.

Lestaevel, P., Romero, E., Dhieux, B., Ben Soussan, H., Berradi, H., Dublineau, I. Voisin, P., Gourmelon, P., 2009. Different pattern of brain pro-/anti-oxidant activity between depleted and enriched uranium in chronically exposed rats. Toxicology 258 (1), 1-9.

Liu, J., Han, D., Li, Y., Zheng, L., Gu, C., Piao, Z., Au, W.W., Xu, X., Huo, X., 2010. Lead affects apoptosis and related gene XIAP and Smac expression in the hippocampus of developing rats. Neurochem. Res. 35 (3), 473-479.

Liu, J., Lewis, G., 2014. Environmental toxicity and poor cognitive outcomes in children and adults. J. Environ. Health 76 (6), 130-138.

McDiarmid, M.A., Hooper, F.J., Squibb, K., McPhaul, K., Engelhardt, S.M., Kane, R. DiPino, R., Kabat, M., 2002. Health effects and biological monitoring results of Gulf War veterans exposed to depleted uranium. Mil. Med. 167 (Suppl. 2), $123-124$.

Ming, G.L., Song, H., 2005. Adult neurogenesis in the mammalian central nervous system. Annu. Rev. Neurosci. 28, 223-250.

Oppenheim, R.W., 1991. Cell death during development of the nervous system. Annu. Rev. Neurosci. 14, 453-501.

Paquet, F., Houpert, P., Blanchardon, E., Delissen, O., Maubert, C., Dhieux, B., Moreels, A.M., Frelon, S., Gourmelon, P., 2006. Accumulation and distribution of uranium in rats after chronic exposure by ingestion. Health Phys. 90 (2), 139-147.

Paternain, J.L., Domingo, J.L., Ortega, A., Llobet, J.M., 1989. The effects of uranium on reproduction, gestation, and postnatal survival in mice. Ecotoxicol. Environ. Saf. 17 (3), 291-296.

Rice, D., Barone Jr., S., 2000. Critical periods of vulnerability for the developing nervous system: evidence from humans and animal models. Environ. Health Perspect. 108 (Suppl. 3), 511-533.

Sanchez, D.J., Belles, M., Albina, M.L., Gomez, M., Linares, V., Domingo, J.L., 2006 Exposure of pregnant rats to uranium and restraint stress: effects on postnatal development and behavior of the offspring. Toxicology 228 (2-3), 323-332.

Schmued, L.C., Stowers, C.C., Scallet, A.C., Xu, L., 2005. Fluoro-Jade C results in ultra high resolution and contrast labeling of degenerating neurons. Brain Res. 1035 (1), 24-31.

Verina, T., Rohde, C.A., Guilarte, T.R., 2007. Environmental lead exposure during early life alters granule cell neurogenesis and morphology in the hippocampus of young adult rats. Neuroscience 145 (3), 1037-1047.

Wappelhorst, O., Kuhn, I., Heidenreich, H., Markert, B., 2002. Transfer of selected elements from food into human milk. Nutrition 18 (4), 316-322. 